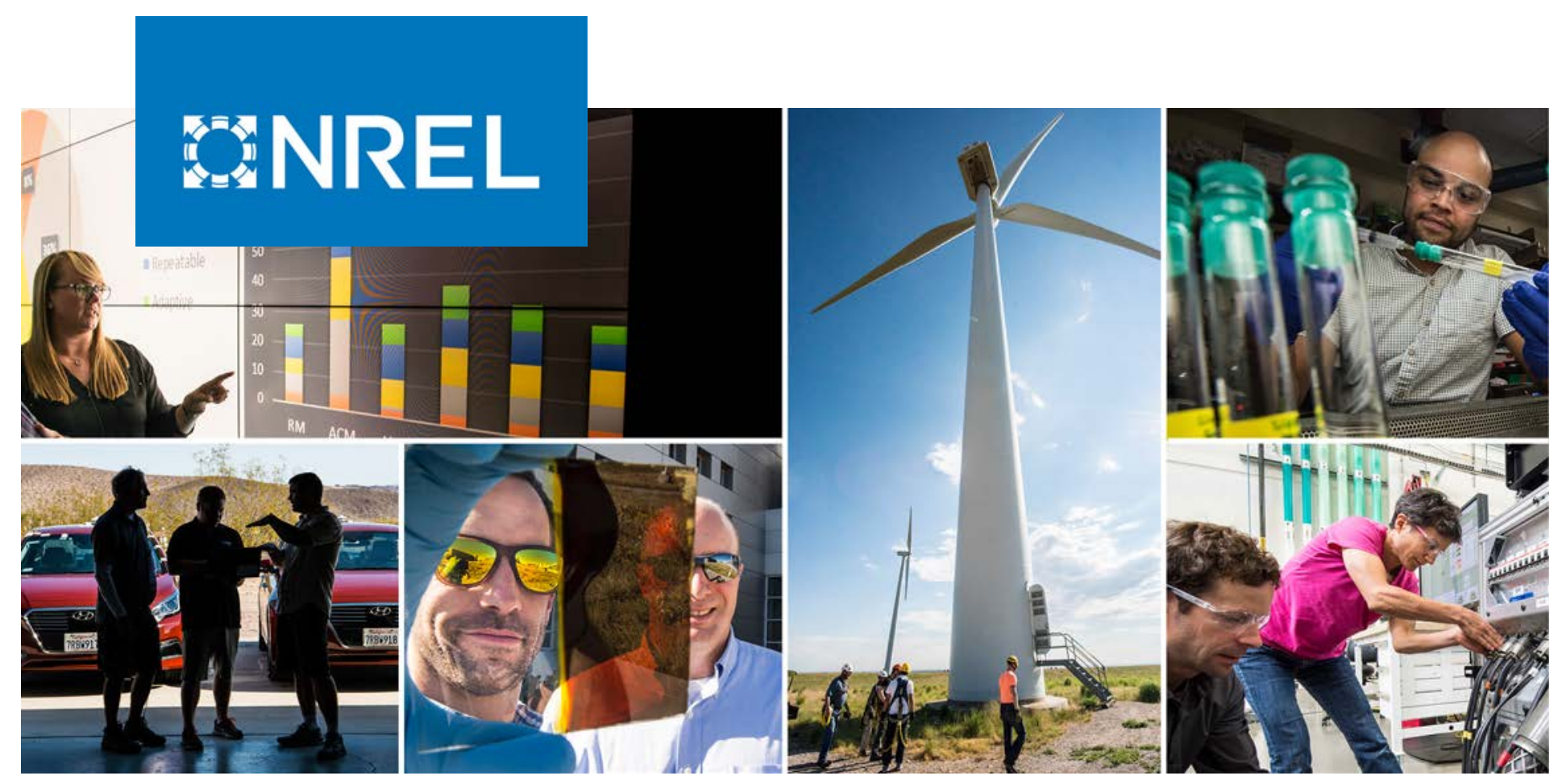

\title{
Energy Efficiency Assessment for a Microgrid in the Community of Castañer, Puerto Rico
}

Khanh Nguyen Cu and Allison Moe

National Renewable Energy Laboratory

NREL is a national laboratory of the U.S. Department of Energy Office of Energy Efficiency \& Renewable Energy

Operated by the Alliance for Sustainable Energy, LLC

This report is available at no cost from the National Renewable Energy Laboratory (NREL) at www.nrel.gov/publications.

\section{Technical Report}

NREL/TP-5500-81877

February 2022 


\title{
GNREL
}

\section{Energy Efficiency Assessment for a Microgrid in the Community of Castañer, Puerto Rico}

\author{
Khanh Nguyen Cu and Allison Moe
}

National Renewable Energy Laboratory

\section{Suggested Citation}

Nguyen $\mathrm{Cu}$, Khanh, and Allison Moe. 2022. Energy Efficiency Assessment for a Microgrid in the Community of Castañer, Puerto Rico. Golden, CO: National Renewable Energy Laboratory. NREL/TP-5500-81877. https://www.nrel.gov/docs/fy22osti/81877.pdf

NREL is a national laboratory of the U.S. Department of Energy Office of Energy Efficiency \& Renewable Energy Operated by the Alliance for Sustainable Energy, LLC

This report is available at no cost from the National Renewable Energy Laboratory (NREL) at www.nrel.gov/publications.

Contract No. DE-AC36-08GO28308
Technical Report

NREL/TP-5500-81877

February 2022

National Renewable Energy Laboratory 15013 Denver West Parkway Golden, CO 80401

303-275-3000 • www.nrel.gov 


\section{NOTICE}

This work was authored by the National Renewable Energy Laboratory, operated by Alliance for Sustainable Energy, LLC, for the U.S. Department of Energy (DOE) under Contract No. DE-AC36-08G028308. Funding provided by the U.S. Department of Energy Better Buildings Workforce Accelerator. The views expressed herein do not necessarily represent the views of the DOE or the U.S. Government.

This report is available at no cost from the National Renewable Energy Laboratory (NREL) at www.nrel.gov/publications.

U.S. Department of Energy (DOE) reports produced after 1991 and a growing number of pre-1991 documents are available free via www.OSTI.gov.

Cover Photos by Dennis Schroeder: (clockwise, left to right) NREL 51934, NREL 45897, NREL 42160, NREL 45891, NREL 48097, NREL 46526.

NREL prints on paper that contains recycled content. 


\section{List of Acronyms}

ECM

HVAC

IREC

NREL

PV

ROI energy conservation measure

heating, ventilating, and air conditioning

Interstate Renewable Energy Council

National Renewable Energy Laboratory

photovoltaic

return on investment 


\section{Table of Contents}

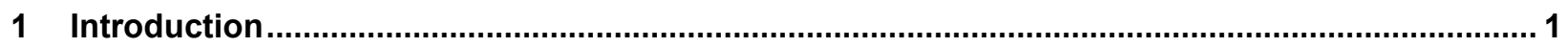

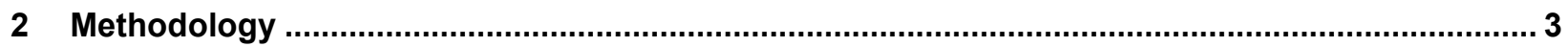

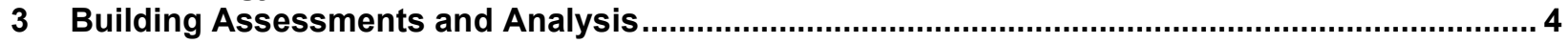

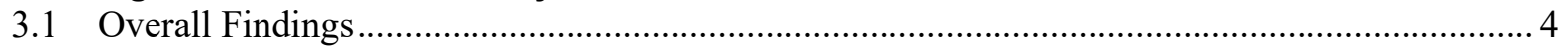

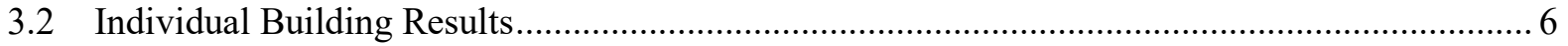

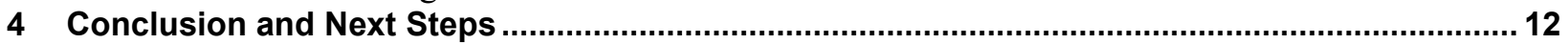

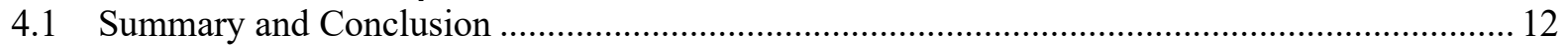

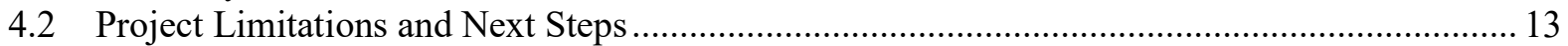

Appendix A. Building Assessment Checklist and Instructions................................................. 15

\section{List of Figures}

Figure 1. Location of Lares, Puerto Rico .......................................................................................... 2

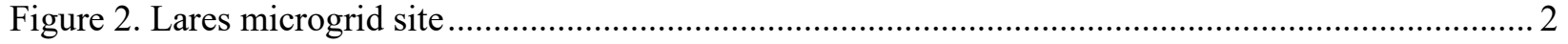

\section{List of Tables}

Table 1. Lares Microgrid Businesses With Highest Energy Use .......................................................... 3

Table 2. Baseline Estimated Annual Electricity Usage for Refrigeration................................................. 5

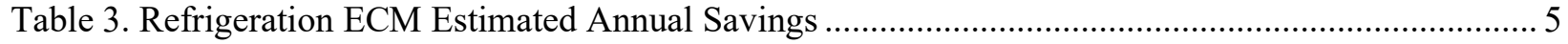

Table 4. Refrigeration Assessment—El Sarten de Fary ........................................................................ 7

Table 5. Refrigeration Assessment — Supermercado Mega-Fresh ......................................................... 8

Table 6. Refrigeration Assessment — Castañer Bakery ......................................................................... 9

Table 7. Refrigeration Assessment—El Tesoro de Cofresí ................................................................... 10

Table 8. Refrigeration Assessment_Panadería y Restaurante La Alborada........................................... 11 


\section{Introduction}

The Cooperativa Hidroeléctrica de la Montaña (Cooperativa) and the Interstate Renewable Energy Council office in Puerto Rico (IREC) are leading the development of a community solar photovoltaic (PV) microgrid comprising a 225-kW DC PV system tied to a 500-kWh storage system in the community of Castañer, in the town of Lares in Puerto Rico. This microgrid will support the electricity needs of eight essential businesses and four homes.

Through IREC's participation in the U.S. Department of Energy's Better Buildings Workforce Accelerator, ${ }^{1}$ the Cooperativa and IREC requested technical assistance to support this microgrid project. Staff from the National Renewable Energy Laboratory (NREL) were selected to conduct a comprehensive energy efficiency assessment for the commercial buildings to maximize the impact of the solar PV microgrid. The main goal was to identify energy conservation measures (ECMs) that would have the highest impact in terms of reducing electricity demand in order to reduce the size and cost of the PV microgrid and in so doing, reduce the annual operating costs for building owners. The second goal was to develop resources and tools to help educate local business owners on the financial benefits of energy efficiency upgrades in conjunction with solar PV. The final goal was goal was to develop resources and tools to train university students on the basic components of energy use analysis.

Because the technical assistance program is limited to 30 hours, the initial scope of the project was reduced to focus on the buildings and appliances with the highest electricity use and associated costs, and which could therefore have the highest potential impact on sizing of the PV microgrid (goal one). The final deliverables for the project are:

1. Analysis of energy usage of refrigeration and lighting equipment for the five buildings with the highest energy use

2. Suggestions for replacement of the above items, with information on energy and cost savings for educating business owners

3. Building Assessment Checklist tool for use in working with university students to collect necessary data for analysis.

For reference, a map of the location of Lares is provided below, followed by a map of the microgrid site and buildings.

\footnotetext{
${ }^{1}$ For more information, see: https://betterbuildingssolutioncenter.energy.gov/accelerators/workforce.
} 


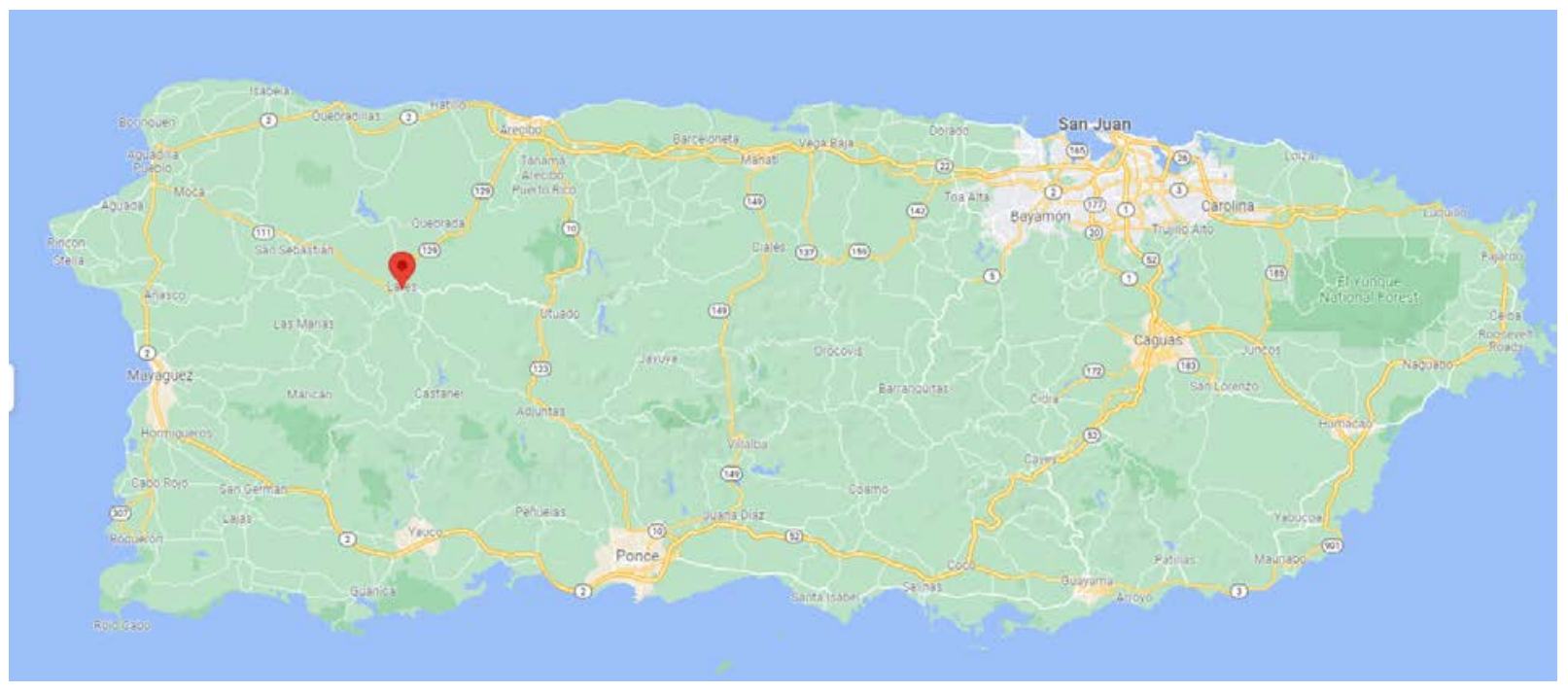

Figure 1. Location of Lares, Puerto Rico

Image from Googlemaps.com

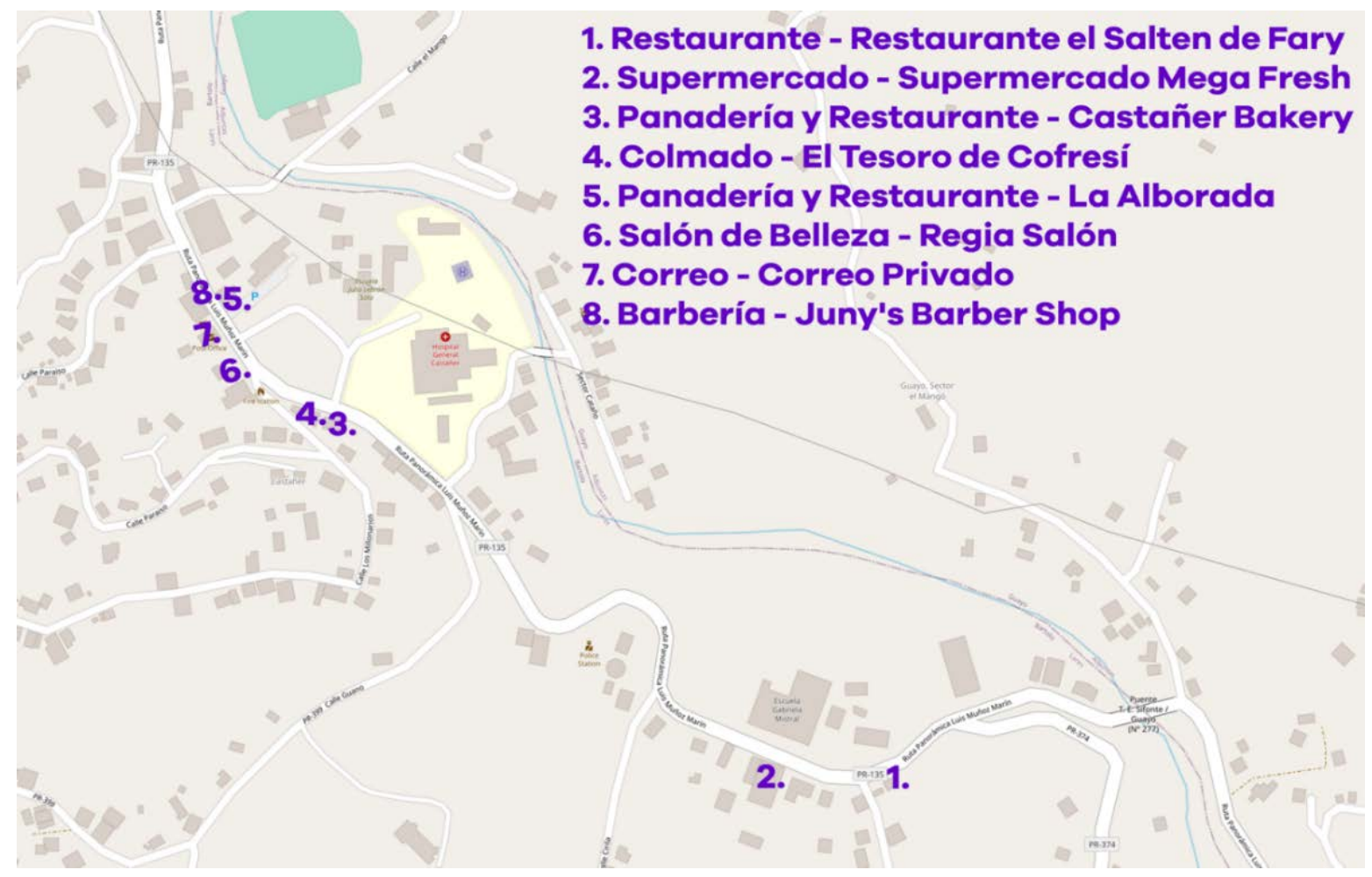

Figure 2. Lares microgrid site

Image from Cooperativa Hidroeléctrica de la Montaña 


\section{Methodology}

The project began with review of utility bills for all eight commercial buildings on the site, in order to identify the buildings with highest energy use to prioritize for further analysis. Those five buildings are shown in Table 1.

Table 1. Lares Microgrid Businesses With Highest Energy Use

\begin{tabular}{|c|l|l|l|l|}
\hline Number & Business Name & $\begin{array}{l}\text { Business } \\
\text { Type }\end{array}$ & Operational Hours & Address \\
\hline 1 & $\begin{array}{l}\text { Restaurante El Sartén } \\
\text { de Fary }\end{array}$ & Restaurant & $\begin{array}{l}6 \text { am-6 pm, Tuesday } \\
\text { to Sunday }\end{array}$ & $\begin{array}{l}\text { Carr 135 km 64.4, } \\
\text { 00631 Castañer, }\end{array}$ \\
\hline 2 & $\begin{array}{l}\text { Supermercado Mega- } \\
\text { Fresh }\end{array}$ & Supermarket & $\begin{array}{l}7 \text { am-7 pm, } \\
\text { Sunday to Saturday }\end{array}$ & $\begin{array}{l}\text { Carr } 135 \mathrm{~km} 64.8, \\
00631 \text { Castañer, }\end{array}$ \\
\hline 3 & $\begin{array}{l}\text { Panadería y } \\
\text { Restaurante Castañer } \\
\text { Bakery }\end{array}$ & Bakery & $\begin{array}{l}6 \text { am-9 pm, } \\
\text { Sunday to Saturday }\end{array}$ & $\begin{array}{l}\text { Carr } 135 \mathrm{~km} 64.0, \\
\text { 00631 Castañer, }\end{array}$ \\
\hline 4 & $\begin{array}{l}\text { Colmado El Tesoro de } \\
\text { Cofresí }\end{array}$ & $\begin{array}{l}\text { Retail and } \\
\text { Cafe }\end{array}$ & $\begin{array}{l}7 \text { am-8 pm, } \\
\text { Sunday to Saturday }\end{array}$ & $\begin{array}{l}\text { Carr 135 km 64.0, } \\
\text { 00631 Castañer, }\end{array}$ \\
\hline 5 & $\begin{array}{l}\text { Panadería y } \\
\text { Restaurante La } \\
\text { Alborada }\end{array}$ & Bakery & $\begin{array}{l}6 \text { am-6 pm, } \\
\text { Monday to Saturday }\end{array}$ & $\begin{array}{l}\text { Carr 135 km 64.0, } \\
\text { 00631 Castañer, }\end{array}$ \\
\hline
\end{tabular}

NREL then worked with the Cooperativa to develop a Building Assessment Checklist for use in conducting an in-person assessment of all electrical appliances in these five buildings. A copy of the checklist can be found in Appendix A. The intention was for this tool to be used by students from the University of Puerto Rico, but time constraints and other challenges required the Cooperativa and IREC staff to conduct the assessments themselves. They hope to use the checklist tool with students on future projects.

The checklist instructs users to complete a form and take photos of each appliance. Based on the picture and nameplate of equipment collected from the assessments, annual energy usage for each item in the categories of heating, ventilating, and air conditioning (HVAC); refrigeration; and lighting was estimated, with the following approaches and assumptions:

- Freezer and refrigerator: We used certified energy use data from either the ENERGY STAR $^{\circledR}$ database or Energy Guide Label based on their nameplate. If certified energy use data for specific unit were not available, an equivalent unit in terms of volume and configuration was chosen as reference. An energy use multiplier ratio of 1.3 was then applied to all data to account for unit age, deterioration, and updated requirements in efficiency.

- Walk-in cooler and freezer: We assumed typical operating cost with estimated sizing from HeatCraft design guidelines with installed capacity.

- HVAC systems: We assumed $0.8 \mathrm{kWh}$ per hour energy usage rate for $12,000 \mathrm{Btu} / \mathrm{hr}$ split air-conditioner with run times (12 hours per day and six days per week). 
- Lighting: Lighting data were not collected, but lighting is an important source of energy consumption. NREL staff assumed a flat $15 \%$ of total building electricity usage (industry standard for building types) based on 12 continuous months of utility bill data. The exception was Supermercado Mega-Fresh, which has significantly more refrigeration equipment, so $10 \%$ was assumed.

From the above baseline operation data, we identified potential savings for each building based using the following sources and assumptions:

- Freezer and refrigerator: ENERGY STAR equipment can be options for retrofit and replacement. We used certificated energy use data of equivalent unit in size and type from ENERGY STAR database or Energy Guide Label to compare with baseline usage.

- Walk-in cooler and freezer: A ratio of 0.85 was applied to baseline usage as result of retrofit effort (typical variable frequency drive upgrade saving).

- HVAC systems: Using $0.6 \mathrm{kWh}$ per hour energy usage rate is equivalent to $25 \%$ saving for a retrofitted HVAC system.

- Lighting: $40 \%$ saving from lighting usage is estimated with LED lighting upgrade from all incandescent.

After reviewing this preliminary data, and based on project time constraints, NREL staff made the decision to conduct a full analysis on refrigeration and freezer appliances only, as these are the highest energy usage and would have the most significant impact overall on the anticipated microgrid size. The analysis was limited to annual operating cost savings of existing appliances versus new efficient appliances, and does not address savings from decreased maintenance and other related costs, as is discussed in the final section of this report. This analysis addresses the first goal of the project, allowing the Cooperativa to assess whether and to what extent they can reduce the size of their microgrid project. It also provides a baseline for educating business owners on the financial impact of energy efficiency upgrades, with further recommended steps to support this second goal offered in the final section of this report.

\section{Building Assessments and Analysis}

\subsection{Overall Findings}

The building assessments were conducted in November and December of 2021. A summary of baseline annual electricity usage, and estimated usage and savings for refrigeration for all five audited buildings are shown in Table 2 and Table 3 . As mentioned above, the findings suggest that refrigeration was the most significant use, with the biggest potential for energy saving and demand reduction. This aligns with initial (pre-audit) estimation with typical energy end-use breakdown because all audited buildings are either a grocery store or restaurant. Refrigeration accounted for $58 \%$ of total energy usage for the five buildings assessed, and as much as $72 \%$ of energy usage for specific buildings. The assessment and analysis results for refrigeration are shown below. 
Table 2. Baseline Estimated Annual Electricity Usage for Refrigeration

\begin{tabular}{|l|l|l|l|l|l|l|}
\hline \multirow{2}{*}{ Business Name } & \multirow{2}{*}{$\begin{array}{l}\text { Tariff } \\
\mathbf{\$} \mathbf{k W h}\end{array}$} & \multicolumn{2}{|l|}{ Total } & \multicolumn{2}{l|}{ Refrigeration } \\
\cline { 5 - 8 } & $\mathbf{k W h}$ & $\mathbf{\$}$ & $\mathbf{k W h}$ & $\mathbf{\$}$ & $\%$ \\
\hline El Sartén de Fary & 0.24 & 13,357 & 3,206 & 5,540 & 1,330 & $41 \%$ \\
\hline Supermercado Mega-Fresh & 0.24 & 133,052 & 31,932 & 78,688 & 18,885 & $59 \%$ \\
\hline Castañer Bakery & 0.21 & 7,246 & 1,522 & 5,181 & 1,088 & $72 \%$ \\
\hline El Tesoro de Cofresí & 0.24 & 11,066 & 2,656 & 3,800 & 912 & $34 \%$ \\
\hline $\begin{array}{l}\text { Panadería y Restaurante } \\
\text { La Alborada }\end{array}$ & 0.22 & 34,274 & 7,540 & 22,068 & 4,855 & $64 \%$ \\
\hline & TOTAL & $\begin{array}{l}198,995 \\
\mathrm{kWh}\end{array}$ & $\mathbf{\$ 4 6 , 8 5 6}$ & $\begin{array}{l}115,277 \\
\mathrm{kWh}\end{array}$ & $\mathbf{\$ 2 7 , 0 7 0}$ & $58 \%$ \\
\hline
\end{tabular}

Following an analysis of the appliances referenced in the above table, this project estimates a total savings of $11 \%$ in annual electricity usage for the microgrid overall, and $\$ 5,194$ annual utility bill savings if all refrigerant retrofit upgrades suggested in this report are installed. The savings are shown in the table below. Detailed results for each building are shown in the following section.

Table 3. Refrigeration ECM Estimated Annual Savings

\begin{tabular}{|l|l|l|l|l|}
\hline \multirow{2}{*}{ Business Name } & \multicolumn{3}{|l|}{ Electricity Savings } & Utility Bill \\
\cline { 2 - 5 } & kWh & $\%$ (Refrig.) & $\%$ (Bldg.) & \\
\hline El Sartén de Fary & 1,236 & $22 \%$ & $9 \%$ & 297 \\
\hline Supermercado Mega-Fresh & 14,217 & $18 \%$ & $11 \%$ & 3,414 \\
\hline Castañer Bakery & 1,357 & $26 \%$ & $19 \%$ & 286 \\
\hline El Tesoro de Cofresí & 822 & $22 \%$ & $7 \%$ & 197 \\
\hline Panadería y Restaurante La Alborada & 4,543 & $21 \%$ & $13 \%$ & 1,000 \\
\hline TOTAL & $22,175 \mathrm{kWh}$ & $19 \%$ & $11 \%$ & $\$ 5,194$ \\
\hline
\end{tabular}

It is important to note that this estimated savings does not include potential savings from maintenance $\operatorname{costs}^{2}$ or increased reliability of the microgrid over the existing utility grid. In addition, while most of buildings have been retrofitted with LED lights, it is important to note that any replacement from old light bulb types (incandescent/fluorescent tube) to LED would save about $40 \%$ of the lighting electricity use, which we estimate at approximately $15 \%$ of overall building energy use for these five buildings.

2 The refrigerant liquid used in existing appliances, like HFC-134 or R404A, will be phased out after 2021. This restriction will significantly increase the maintenance cost because the cost of phased-out refrigerant might be triple their replacement ones.

Dao, Elenee. 2019. "Freon refrigerant to become more expensive as it is phased out." KMVT.com https:/www.kmvt.com/content/news/Type-of-refrigerant-to-get-more-expensive-as-it-gets-phased-out$\underline{512564702 . h t m l}$. 


\subsection{Individual Building Results}

This section includes tables describing the recommended refrigeration ECMs for each of the five buildings analyzed for this project. Each table includes the item, suggested replacement, and estimated replacement cost based on pickup or delivery to Jacksonville, Florida (zip code 32034). This location was used as a point of importation into Puerto Rico, as local pricing was not readily available. Some equipment manufacturers required submittal of an official quote to obtain pricing, for which there was not time in this project. This has been noted in the following tables. Any equivalent model in size and configuration that has ENERGY STAR ${ }^{\circledR}$ certification should be eligible for retrofit recommendation. These costs were taken in December of 2021 and are subject to change.

For all individual building tables, the "size" column describes the estimated sizing value for each equipment type: in cubic feet for refrigerator and freezer, dimension in feet (width $\mathrm{x}$ length $\mathrm{x}$ height) for walk-in freezers and coolers, tank number for slush machine, and Btu/hr for air conditioner. 
Table 4. Refrigeration Assessment-EI Sarten de Fary

\begin{tabular}{|c|c|c|c|c|c|c|c|c|}
\hline Equipment & Quantity & Equipment Type & Size & $\begin{array}{l}\text { Suggested } \\
\text { Replacement } \\
\text { Model }\end{array}$ & $\begin{array}{l}\text { Annual } \\
\text { Baseline } \\
\text { kWh }\end{array}$ & $\begin{array}{l}\text { Annual ECM } \\
\text { kWh }\end{array}$ & $\begin{array}{l}\text { Annual } \\
\text { ECM Cost } \\
\text { Savings \$ }\end{array}$ & $\begin{array}{l}\text { Estimated } \\
\text { Replacement } \\
\text { Cost } \$\end{array}$ \\
\hline $\begin{array}{l}\text { Air } \\
\text { conditioner }\end{array}$ & 1 & $\begin{array}{l}\text { Split air } \\
\text { conditioner }\end{array}$ & $\begin{array}{l}12,000 \\
\text { Btu/hr }\end{array}$ & $\begin{array}{l}\text { PREMIUM - } \\
\text { PIAW12166A } \\
\end{array}$ & 3,003 & 2253 & 180 & 691 \\
\hline $\begin{array}{l}\text { Slush } \\
\text { machine }\end{array}$ & 1 & Slush machine & $\begin{array}{l}2 \\
\text { tanks }\end{array}$ & Bunn ULTRA-2 HP & 1,564 & 1304 & 63 & 2,400 \\
\hline Refrigerator & 1 & $\begin{array}{l}\text { Vertical 1-glass- } \\
\text { door refrigerator }\end{array}$ & $26 \mathrm{ft}^{3}$ & $\begin{array}{l}\text { Beverage-Air } \\
\text { MMR27HC-1-W-18 }\end{array}$ & 973 & 748 & 54 & 3,841 \\
\hline \multicolumn{5}{|r|}{ TOTAL } & $5,540 \mathrm{kWh}$ & $4,305 \mathrm{kWh}$ & $\$ 297$ & $\$ 6,932$ \\
\hline
\end{tabular}


Table 5. Refrigeration Assessment-Supermercado Mega-Fresh

\begin{tabular}{|c|c|c|c|c|c|c|c|c|}
\hline Equipment & Quantity & Equipment Type & $\begin{array}{l}\text { Size } \\
\mathrm{ft}^{3}\end{array}$ & $\begin{array}{l}\text { Suggested } \\
\text { Replacement } \\
\text { Model }\end{array}$ & $\begin{array}{l}\text { Annual } \\
\text { Baseline } \\
\text { kWh }\end{array}$ & $\begin{array}{l}\text { Annual ECM } \\
\text { kWh }\end{array}$ & $\begin{array}{l}\text { Annual } \\
\text { ECM Cost } \\
\text { Savings \$ }\end{array}$ & $\begin{array}{l}\text { Estimated } \\
\text { Replacement } \\
\text { Cost \$ }\end{array}$ \\
\hline Freezer & 1 & Walk-in freezer & $\begin{array}{l}10 x \\
12\end{array}$ & $\begin{array}{l}\text { Requires installation } \\
\text { contractor }\end{array}$ & 48,804 & 41,483 & 1,757 & $\begin{array}{l}\text { Quote } \\
\text { needed }\end{array}$ \\
\hline Freezer & 1 & $\begin{array}{l}\text { Vertical 5-glass- } \\
\text { door freezer }\end{array}$ & 70 & $\begin{array}{l}\text { Panama Green 3D: } \\
\underline{2500 \mathrm{~F}}\end{array}$ & 14,710 & 11,315 & 815 & $\begin{array}{l}\text { Quote } \\
\text { needed }\end{array}$ \\
\hline Refrigerator & 1 & $\begin{array}{l}\text { Vertical 1-glass- } \\
\text { door refrigerator }\end{array}$ & 12.3 & $\begin{array}{l}\text { Beverage-Air } \\
\text { HBR12HC }\end{array}$ & 698 & 537 & 39 & 3,129 \\
\hline Refrigerator & 1 & $\begin{array}{l}\text { Vertical 3-glass- } \\
\text { door refrigerator }\end{array}$ & 66 & $\begin{array}{l}\text { True GDM-72FC- } \\
\text { HC } \sim \text { TSL01 } \\
\end{array}$ & 2,325 & 1,789 & 129 & 6,763 \\
\hline Refrigerator & 1 & $\begin{array}{l}\text { Vertical 4-glass- } \\
\text { door refrigerator }\end{array}$ & 125 & $\frac{\text { Hoshizaki - R3A-HG }}{\text { (Multiplier with 1.5) }}$ & 4,626 & 3,559 & 256 & 15,225 \\
\hline Refrigerator & 3 & $\begin{array}{l}\text { Vertical 2-glass- } \\
\text { door refrigerator }\end{array}$ & 50 & $\frac{\text { Continental - }}{\text { 2RENGDHD }}$ & $1,637(x 3)$ & $1,259(x 3)$ & $91(x 3)$ & $8,426(x 3)$ \\
\hline Refrigerator & 1 & $\begin{array}{l}\text { Vertical 2-glass- } \\
\text { door refrigerator }\end{array}$ & 40 & $\begin{array}{l}\text { True GDM-49FC- } \\
\underline{\mathrm{HC}}\end{array}$ & 1,708 & 1,314 & 95 & 6,096 \\
\hline Refrigerator & 1 & $\begin{array}{l}\text { Vertical 1-glass- } \\
\text { door refrigerator }\end{array}$ & 17 & $\underline{\text { True GDM-19T-HC }}$ & 906 & 697 & 50 & 2,802 \\
\hline \multicolumn{5}{|r|}{ TOTAL } & $78,688 \mathrm{kWh}$ & $64,471 \mathrm{kWh}$ & $\$ 3,414$ & $\$ 59,293^{*}$ \\
\hline
\end{tabular}

* Total does not include cost of appliances that required a quote to obtain pricing. 
Table 6. Refrigeration Assessment-Castañer Bakery

\begin{tabular}{|c|c|c|c|c|c|c|c|c|}
\hline Equipment & Quantity & Equipment Type & $\begin{array}{l}\text { Size } \\
\mathrm{ft}^{3}\end{array}$ & $\begin{array}{l}\text { Suggested } \\
\text { Replacement Model }\end{array}$ & $\begin{array}{l}\text { Annual } \\
\text { Baseline } \\
\text { kWh }\end{array}$ & $\begin{array}{l}\text { Annual ECM } \\
\text { kWh }\end{array}$ & $\begin{array}{l}\text { Annual } \\
\text { ECM Cost } \\
\text { Savings \$ }\end{array}$ & $\begin{array}{l}\text { Estimated } \\
\text { Replacement } \\
\text { Cost \$ }\end{array}$ \\
\hline Freezer & 1 & Ice cream freezer & 15 & $\begin{array}{l}\text { Any equivalent with } \\
\text { R290/R32 }\end{array}$ & 600 & 300 & 63 & Quote needed \\
\hline Refrigerator & 1 & $\begin{array}{l}\text { Vertical 1-glass- } \\
\text { door refrigerator }\end{array}$ & 17 & $\underline{\text { True GDM-19T-HC }}$ & 906 & 697 & 44 & 2,802 \\
\hline Refrigerator & 1 & $\begin{array}{l}\text { Vertical 3-glass- } \\
\text { door refrigerator }\end{array}$ & 66 & $\begin{array}{l}\text { True GDM-72- } \\
\underline{\text { HC TSL01 }} \\
\end{array}$ & 2,325 & 1,789 & 113 & 6,763 \\
\hline Freezer & 3 & Chest freezer & 21 & GE - FCM22DL & $450(\times 3)$ & $346(x 3)$ & $22(x 3)$ & $962(x 3)$ \\
\hline \multicolumn{5}{|l|}{ TOTAL } & $5,181 \mathrm{kWh}$ & $3,824 \mathrm{kWh}$ & $\$ 286$ & $\$ 11,489^{*}$ \\
\hline
\end{tabular}

* Total does not include cost of appliances which required a quote to obtain pricing. 
Table 7. Refrigeration Assessment-EI Tesoro de Cofresí

\begin{tabular}{|c|c|c|c|c|c|c|c|c|}
\hline Equipment & Quantity & Equipment Type & $\begin{array}{l}\text { Size } \\
\mathrm{ft}^{3}\end{array}$ & $\begin{array}{l}\text { Suggested } \\
\text { Replacement Model }\end{array}$ & $\begin{array}{l}\text { Annual } \\
\text { Baseline } \\
\text { kWh }\end{array}$ & $\begin{array}{l}\text { Annual ECM } \\
\text { kWh }\end{array}$ & $\begin{array}{l}\text { Annual } \\
\text { ECM Cost } \\
\text { Savings \$ }\end{array}$ & $\begin{array}{l}\text { Estimated } \\
\text { Replacement } \\
\text { Cost \$ }\end{array}$ \\
\hline Refrigerator & 1 & $\begin{array}{l}\text { Vertical 1-glass- } \\
\text { door refrigerator }\end{array}$ & 12.3 & $\begin{array}{l}\text { Beverage-Air } \\
\underline{\text { HBR12HC }}\end{array}$ & 698 & 537 & 39 & 3,129 \\
\hline Refrigerator & 1 & Refrigerator & 15.6 & GE - GTE16DTN & 469 & 345 & 30 & 674 \\
\hline Freezer & 1 & Chest freezer & 9 & $\begin{array}{l}\text { Whirlpool - } \\
\text { WZC3209LW }\end{array}$ & 223 & 201 & 5 & 550 \\
\hline Freezer $^{3}$ & 1 & Chest freezer & 9 & $\begin{array}{l}\text { Whirlpool - } \\
\text { WZC3209LW }\end{array}$ & 261 & 201 & 14 & 550 \\
\hline Freezer & 1 & Upright freezer & 14.1 & $\underline{\text { GE - FUF14DL }}$ & 442 & 397 & 11 & 850 \\
\hline Refrigerator & 1 & Refrigerator & 15.6 & GE - GTE16DTN & 469 & 345 & 30 & 674 \\
\hline Refrigerator & 1 & Horizontal fridge & 20 & $\begin{array}{l}\text { True TMC-58-S-DS- } \\
\underline{\text { SS-HC }}\end{array}$ & 460 & 354 & 25 & 5,350 \\
\hline Refrigerator & 1 & $\begin{array}{l}\text { Vertical 1-glass- } \\
\text { door refrigerator }\end{array}$ & 14 & $\frac{\text { Turbo Air - TGM- }}{15 \mathrm{SD}^{*} \text {-N6 }}$ & 778 & 599 & 43 & 2,731 \\
\hline \multicolumn{5}{|r|}{ TOTAL } & $3,800 \mathrm{kWh}$ & $2,978 \mathrm{kWh}$ & $\$ 197$ & $\$ 14,508$ \\
\hline
\end{tabular}

\footnotetext{
${ }^{3}$ Increase Baseline Energy usage due to equipment condition captured.
} 
Table 8. Refrigeration Assessment-Panadería y Restaurante La Alborada

\begin{tabular}{|c|c|c|c|c|c|c|c|c|}
\hline Equipment & Quantity & Equipment Type & $\begin{array}{l}\text { Size } \\
\mathrm{ft}^{3}\end{array}$ & $\begin{array}{l}\text { Suggested } \\
\text { Replacement Model }\end{array}$ & $\begin{array}{l}\text { Annual } \\
\text { Baseline } \\
\text { kWh }\end{array}$ & $\begin{array}{l}\text { Annual ECM } \\
\text { kWh }\end{array}$ & $\begin{array}{l}\text { Annual } \\
\text { ECM Cost } \\
\text { Savings } \$\end{array}$ & $\begin{array}{l}\text { Estimated } \\
\text { Replacement } \\
\text { Cost } \$\end{array}$ \\
\hline Freezer & 1 & Ice maker & & $\begin{array}{l}\text { Blue Air - BLUI- } \\
\underline{250 \mathrm{~A}-\mathrm{HC}}\end{array}$ & 3,788 & 2,288 & 330 & 3,007 \\
\hline Refrigerator & 1 & Walk-in cooler & $\begin{array}{l}8 \times 8 \\
\times 8\end{array}$ & $\begin{array}{l}\text { Required installation } \\
\text { contractor }\end{array}$ & 14,172 & 12,047 & 468 & Quote needed \\
\hline Freezer & 1 & Chest freezer & 21 & GE - FCM22DL & 450 & 346 & 23 & 962 \\
\hline Refrigerator & 1 & Salad refrigerator & 7 & $\frac{\text { KOOL-IT - KUCR-27- }}{1}$ & 280 & 215 & 14 & 1,737 \\
\hline Freezer & 1 & Chest freezer & 9 & $\begin{array}{l}\text { Whirlpool - } \\
\text { WZC3209LW }\end{array}$ & 223 & 201 & 5 & 550 \\
\hline Refrigerator & 1 & $\begin{array}{l}\text { Vertical 2-glass- } \\
\text { door refrigerator }\end{array}$ & 15 & $\begin{array}{l}\text { True GDM-35SL-RF- } \\
\underline{\text { HC-LD }}\end{array}$ & 830 & 639 & 42 & 5,587 \\
\hline Refrigerator & 1 & $\begin{array}{l}\text { Vertical 3-glass- } \\
\text { door refrigerator }\end{array}$ & 66 & $\underline{\text { True GDM-72FC-HC }}$ & 2,325 & 1,789 & 118 & 6,763 \\
\hline \multicolumn{5}{|l|}{ TOTAL } & $22,068 \mathrm{kWh}$ & $17,525 \mathrm{kWh}$ & $\$ 1,000$ & $\$ 15,599^{*}$ \\
\hline
\end{tabular}

* Total does not include cost of appliances that required a quote to obtain pricing. 


\section{Conclusion and Next Steps}

\subsection{Summary and Conclusion}

The primary goal of this project was to identify ECMs that would have the highest impact in terms of reducing electricity demand to reduce the size and cost of the PV microgrid and reduce the annual operating costs for building owners. A secondary goal was to train and educate building owners on the financial value of energy efficiency. The final goal was to engage and train local university students in energy assessments. The findings summarized below support the first two goals. Unfortunately, due to time constraints this project was not able to engage with local university students. However, the professor was included in the process, and a Building Assessment Checklist was created, which could be used on future projects.

In working within the 30-hour limit of this project, the NREL team focused on refrigeration in the five buildings with the highest energy use, as this would have the most significant impact on sizing the microgrid, and on future operating costs for business owners. If all replacements identified in this report were completed, this could result in $11 \%$ energy savings in these five buildings compared to the baseline, which translates to more than $\$ 5,000$ per year in energy bill costs. This savings is a baseline, and does not include further cost savings on maintenance of existing appliances, or savings anticipated from decreased reliance on back-up diesel power, as discussed in the following section.

It is likely that not all the refrigeration ECMs will be taken in the near future due to financial constraints, therefore the following items are recommended for most immediate replacement. Just replacing these five items could reduce overall energy consumption by 15,408 $\mathrm{kWh}$. Based on the current microgrid design $(225 \mathrm{~kW}$ and $500 \mathrm{kWh}$ in storage), replacing just these five items could reduce the system size by $8 \%$.

1. Supermercado Mega-Fresh-Walk-in freezer, size $10 \times 12 \mathrm{ft}$

○ Annual electricity usage saving: 7,321 kWh

- Annual cost savings: $\$ 1,757$

2. Supermercado Mega-Fresh-Vertical 5-glass-door freezer, size $70 \mathrm{ft}^{3}$

- Annual electricity usage saving: 3,395 kWh

○ Annual cost savings: $\$ 815$

3. Supermercado Mega-Fresh-Vertical 4-glass-door refrigerator, size $125 \mathrm{cub} . \mathrm{ft}$

○ Annual electricity usage saving: $1,067 \mathrm{kWh}$

○ Annual cost savings: $\$ 256$

4. Panadería y Restaurante La Alborada-Walk-in cooler, size $8 \times 8 \times 8 \mathrm{ft}$

○ Annual electricity usage saving: 2,125 kWh

○ Annual cost savings: $\$ 468$

5. Panadería y Restaurante La Alborada-Ice maker

○ Annual electricity usage saving: $1,500 \mathrm{kWh}$

○ Annual cost savings: $\$ 330$ 
It should be acknowledged that while annual operating savings on the above items is significant, the replacement cost of these items is also very high, with payback periods ranging from 10 years to 60 years. This payback period can be reduced by including a more complete return on investment study as described in the following section.

Finally, appliance replacement could further be prioritized based on the age of appliances. Many of the appliances in use are 8 to 20 years old and likely nearing the end of their life cycles. When building owners are faced with a necessary appliance replacement (versus a voluntary one), the annual operating cost savings of a more efficient appliance becomes much more valuable and important to decision-making, as the "sunk cost" is no longer a part of the return on investment calculation.

We did not receive age information for all appliances and could not conduct a full analysis based on age. However given average expected appliance lifetimes as well as new requirements on efficiency starting in 2022, we recommend prioritizing upgrading any appliance which is more than 8 years old. While the overall impact of these reductions may not be as meaningful to the system size or overall operational cost savings, it may be a more realistic approach to decision making for the business owners.

\subsection{Project Limitations and Next Steps}

Due to the limited nature of the Better Buildings Workforce Accelerator technical assistance program, this project was not able to fully address the second educational aspect of the project's goal, which was to understand and clearly communicate the energy and cost savings opportunities to the business' owners in the Community of Castañer. Specific limitations or research areas missing include identifying annual energy and cost savings for all appliances, identifying existing maintenance costs for the current appliances, understanding the financial impact of current grid reliability issues, and getting accurate local pricing for replacement items.

Based on these limitations, we suggest the following next steps for the IREC team and its community partners. These will help ensure that this project can be truly useful in educating local businesses in Castañer about implementing the ECMs described in this report.

- Maintenance costs: Because most of the existing equipment reviewed for this project is 8 to 20 years old, it is likely that business owners have regular maintenance costs to keep these appliances in working conditions. However, the project team did not have access to this information. In addition, we know that the cost of refrigerant will start to increase significantly in coming years due to changes in federal standards, which will add additional costs for maintenance. Understanding and quantifying this cost will increase the annual financial savings of operating replacement appliances beyond the savings discussed in Section 3.

- Diesel fuel costs: Castañer suffers frequent and extended electrical outages, during which they run on diesel-fueled generators. Typical cost for a kilowatt-hour is about 80 cents. Quantifying how frequently (days per year and hours per day) businesses run on generators will increase the annual financial savings of operating replacement appliances beyond the savings discussed in Section 3. 
- Local pricing: The estimated replacement costs shown in Section 3 are a proxy and were not complete, as some equipment required official quotes to be submitted. Research to quantify more precise local pricing will be necessary to have real conversations with business owners about replacing items.

- Return on investment (ROI): If IREC is able to collect the information identified above, and combine it with the annual ECM cost savings described in this report, they will be able to develop a full ROI analysis for each appliance to present to business owners. This would be achieved by using the following equation:

Local Replacement Cost

(annual ECM cost savings + annual maintenance cost + annual diesel fuel costs)

The result would be the number of years it would take for a specific ECM to pay for itself. Those with the lowest ROI could be prioritized for replacement even if the existing unit still functions. But even those with higher ROIs will demonstrate their value, as at some point in the future all appliances will need to be replaced. It can therefore be helpful for business owners to understand the financial value of replacing nonfunctioning appliances with higher-quality appliances. 


\section{Appendix A. Building Assessment Checklist and Instructions}

\section{Address/Building:}

Directions: Fill out the form below for every item used in each building that plugs in/uses electricity. Please be as thorough as possible.

$\diamond \quad$ Note: Please add note if building is mixed type (store and family housing)

$\diamond \quad$ Check with occupant about operation hours (weekdays/weekend schedule)

- Item: Refers to the specific item you are looking at. For any not on the list, please describe item. Note: If there are multiple items in the building please add a suffix (e.g., ceiling fan A/B) and put them in different rows.

- Power: Look on the energy use sticker (see photo below) for the power number, labeled as HP

- Current: Look on the energy use sticker (see photo below) for the current number, labeled in amps

- Operational Info/Schedule: Check with occupant or take picture on equipment nameplate/panel

- Item plugs in permanently or occasionally? How many hours does equipment run on weekdays/weekend?

- Settings of equipment:

- Thermostat:

- Thermostat cooling and heating setpoints (see example on thermostat at $72^{\circ} \mathrm{F}$ as below)

- Programable thermostat (schedule): Ask occupant if they change the settings over time of day

- Refrigeration equipment:

- Setpoints-see below settings (freezer temperature settings at 4 of range $1-7$ as below)

- Setpoint schedule: Ask occupant if they change the settings over time of day

- Photo of Item: Take a photo of each item, AND where possible, a photo of the energy use sticker (see examples below). Check the box with an $\mathrm{X}$ if you were able to take a photo.

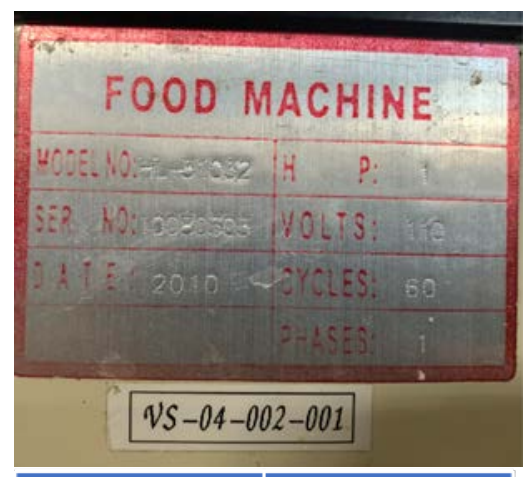

\section{\begin{tabular}{l|l} 
Power & $1 \mathrm{HP}$ \\
\hline
\end{tabular}}

Current $6.7 \mathrm{~A}$

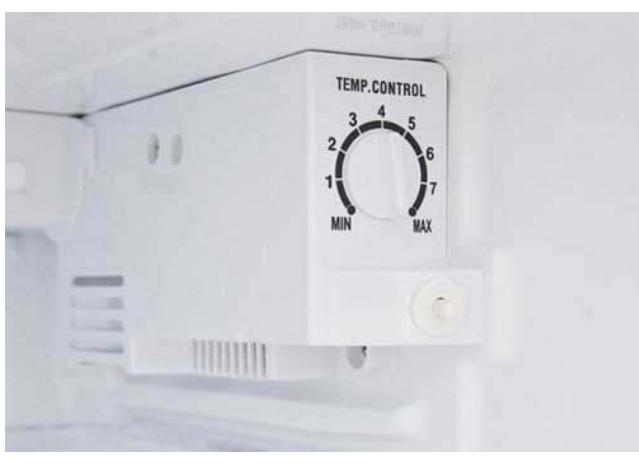

Freezer: Temperature settings at 4 of range $1-7$

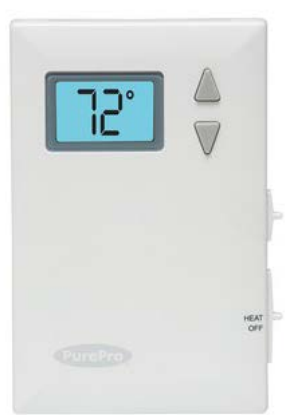

Thermostat setpoint at $72^{\circ} \mathrm{F}$ 


\begin{tabular}{|c|c|c|c|c|c|}
\hline \multirow[b]{3}{*}{ Item } & \multicolumn{5}{|c|}{ HVAC } \\
\hline & \multirow[b]{2}{*}{ Items } & \multirow{2}{*}{$\begin{array}{l}\text { Photo of Item/ } \\
\text { Sticker }\end{array}$} & \multicolumn{2}{|c|}{ Nameplate (If Have) } & \multirow{2}{*}{$\begin{array}{l}\text { Operational } \\
\text { Info/Schedule }\end{array}$} \\
\hline & & & $\begin{array}{l}\text { Power } \\
\text { (HP) }\end{array}$ & $\begin{array}{l}\text { Current } \\
\text { (Amps) }\end{array}$ & \\
\hline 1 & Thermostat & & & & \\
\hline 2 & Ceiling fan & & & & \\
\hline 3 & Heater & & & & \\
\hline 4 & Air conditioner & & & & \\
\hline 5 & HVAC system & & & & \\
\hline 6 & Kitchen exhaust hood & & & & \\
\hline 7 & Restroom fan & & & & \\
\hline 8 & Other (write in description): & & & & \\
\hline 9 & Other (write in description): & & & & \\
\hline 10 & Other (write in description): & & & & \\
\hline
\end{tabular}

\begin{tabular}{|c|l|l|l|l|l|}
\hline \multicolumn{5}{|c|}{ Refrigeration and Kitchen Equipment } \\
\hline \multirow{2}{*}{ Item } & Items & $\begin{array}{l}\text { Photo of Item/ } \\
\text { Sticker }\end{array}$ & $\begin{array}{l}\text { Nameplate (If Have) } \\
\text { (HP) }\end{array}$ & $\begin{array}{l}\text { Current } \\
\text { (Amps) }\end{array}$ & $\begin{array}{l}\text { Operational } \\
\text { Info/Schedule }\end{array}$ \\
\hline 1 & Refrigerator & & & & \\
\hline 2 & Freezer & & & & \\
\hline 3 & Ice machine & & & & \\
\hline 4 & Beverage machine & & & & \\
\hline 5 & Oven/range & & & & \\
\hline 6 & Freezer & & & & \\
\hline 7 & Microwave & & & & \\
\hline 8 & Other (write in description): & & & & \\
\hline 9 & Other (write in description): & & & & \\
\hline 10 & Other (write in description): & & & & \\
\hline
\end{tabular}

\begin{tabular}{|c|l|l|l|}
\hline \multicolumn{2}{|c|}{ Lighting } & $\begin{array}{l}\text { Number of } \\
\text { Items }\end{array}$ & Photo of Item/Sticker \\
\hline Item & Items & & \\
\hline 2 & Incandescent light bulbs & & \\
\hline 3 & Fluorescent light bulbs & & \\
\hline 4 & LED light bulbs & & \\
\hline 5 & Oube lights & & \\
\hline 6 & Other (write in description): & & \\
\hline 7 & Other (write in description): & & \\
\hline
\end{tabular}

